\title{
Deoxyribonucleic Acid Relatedness of Proteus and Providencia Species
}

\author{
DON J. BRENNER, ${ }^{1}$ J. J. FARMER III, ${ }^{1}$ G. R. FANNING, ${ }^{2}$ A. G. STEIGERWALT, ${ }^{1}$ PAAL \\ KLYKKEN, ${ }^{2}$ H. G. WATHEN, ${ }^{1}$ F. W. HICKMAN, ${ }^{1}$ AND W. H. EWING ${ }^{\dagger}$ \\ Enteric Section, Center for Disease Control, Atlanta, Georgia 30333, ${ }^{1}$ and Division of Biochemistry, Walter \\ Reed Army Institute of Research, Washington, D.C. $20012^{2}$
}

\begin{abstract}
Deoxyribonucleic acid reassociation was used to determine relatedness among protei and providenciae and between these organisms and other members of the family Enterobacteriaceae. The results indicate the following. (i) Proteus mirabilis, Prot. morganii, and Providencia stuartii are homogeneous species. (ii) Prot. vulgaris, Prot. rettgeri, and Prov. alcalifaciens each contain more than one deoxyribonucleic acid relatedness group. (iii) A group of urea-positive strains previously called Prot. rettgeri biogroup 5 are, in fact, members of Prov. stuartii. (iv) Prot. myxofaciens is a valid species. (v) Protei are only distantly related to all other Enterobacteriaceae. Taxonomic revisions consistent with these observations are discussed. These include a proposal to place the currently recognized species of Proteus into one of three genera: the genus Proteus, containing Prot. mirabilis Hauser, Prot. vulgaris Hauser, and Prot. myxofaciens Cosenza and Podgwaite; a separate genus Morganella Fulton, for Prot. morganii (Winslow et al.) Yale; and the genus Providencia containing Prov. alcalifaciens (De Salles Gomes) Ewing, Prov. stuartii (Buttiaux et al.) Ewing, and Prov. rettgeri comb. nov.
\end{abstract}

In Bergey's Manual of Determinative Bacte. riology, 8th ed., Lautrop (29) recognized five species of Proteus Hauser: Prot. vulgaris Hauser, Prot. mirabilis Hauser, Prot. morganii (Winslow, Kligler, and Rothberg) Yale, Prot. rettgeri (Hadley, Elkins, and Caldwell) Rustigian and Stuart, and Prot. inconstans (Ornstein) Shaw and Clarke. Ewing (13-16) placed Prot. inconstans in the genus Providencia Ewing and recognized two species: Prov. alcalifaciens (De Salles Gomes) Ewing and Prov. stuartii (Buttiaux et al.) Ewing.

Ewing described four biogroups in Prov. alcalifaciens and two biogroups in Prov. stuartii. These are based on the production of gas from glucose and the fermentation of adonitol and inositol (17; see Table 12).

Several other taxonomic proposals for Proteus and Providencia have been reviewed by Rauss (38). The best known of these is Kauffmann's recommendation of four genera: Proteus, Morganella, Rettgerella, and Providencia (26). Kauffmann included Prot. mirabilis and Prot. vulgaris in the species Prot. hauseri. The fourgenus concept with Prot. hauseri was endorsed by Rauss (38), and Coetzee (7) endorsed the four-genus system while retaining $P$. mirabilis and $P$. vulgaris.

Johnson et al. (24) studied 50 strains of Pro-

$\dagger$ Present address: P.O. Box 33276, Decatur, GA 30033. teus and Providencia by numerical taxonomy. They objected to separating Proteus from Providencia mainly on the basis of urease production. They also noted a large proportion of biochemically atypical strains of protei. This observation and observations of multiple antibiotic resistance in protei are well documented $(8,9$, $12,13,16,17,21,22,30,32,33)$. Expanding upon the earlier work of Namioka and Sakazaki (31), Penner et al. (34) divided Prot. rettgeri into five biogroups based on acid production from salicin, L-rhamnose, D-mannitol, adonitol, and D-arabitol. Biogroup (BG) 5 did not produce acid from the three polyhydric alcohols and resembled some strains of Prot. stuartii. These authors suggested that their BG 5 may be intermediate between Prot. rettgeri and Providencia.

In a review (7), Coetzee documented serological differences in enzymes among protei. Therefore, there are antigenic, structural, and biochemical data that suggest genetic divergence among protei. With the exception of Prot. mor ganii (50 mol\% guanine plus cytosine $[\mathrm{G}+\mathrm{C}]$ in the deoxyribonucleic acid [DNA]), Proteus and Providencia species have substantially lower $\mathrm{G}+\mathrm{C}$ ratios than other Enterobacteriaceae, whose DNA contains 50 to $58 \mathrm{~mol} \% \mathrm{G}+\mathrm{C}$. Prot. mirabilis and Prot. vulgaris contain 38 to 40 $\mathrm{mol} \% \mathrm{G}+\mathrm{C}(19,23,29)$, Prot. rettgeri has 39 to $41.5 \mathrm{~mol} \% \mathrm{G}+\mathrm{C}$, and providenciae are reported to have 40 to $42 \mathrm{~mol} \% \mathrm{G}+\mathrm{C}$. 
A few laboratories have reported DNA relatedness studies on protei $(1,2,7,11,25)$, and the data from these studies are summarized by Coetzee (7). These preliminary data indicate that Prot. mirabilis and Prot. vulgaris contain similar base sequences throughout a substantial portion of their genomes $(1,7)$, whereas neither of these species is closely related to other protei or to Escherichia coli $(1,2,7)$. Prot. morganii and Prot. rettgeri do not exhibit substantial relatedness to each other, to Providencia, or to $E$. coli $(7,11)$.

In this study, we determined the degree of DNA relatedness within and among species of Proteus and Providencia and also the relatedness of these organisms to other Enterobacteriaceae. A revised classification of the tribe Proteeae is proposed based on nucleic acid relatedness data. There are also some nomenclatural problems and a need for neotype strains to be designated. These problems will be considered in a subsequent paper.

\section{MATERIALS AND METHODS}

Bacterial strains and media. The organisms used in this study are listed in Table 1. Proteus and Providencia strains are listed by the name under which they were received. Organisms were maintained on brain heart infusion agar or nutrient agar. Routine cultivation was carried out in brain heart infusion broth on a dry-air rotary shaker at $37^{\circ} \mathrm{C}$. The medium used for labeling cells with ${ }^{32} \mathrm{PO}_{4}$ was described previously (2).

Preparation of DNA. A modification of the method of Berns and Thomas (2) was used in preparing both unlabeled and ${ }^{32} \mathrm{PO}_{4}$-labeled DNA. DNA was sheared by sonic oscillation to an average doublestranded molecular weight of approximately $2.5 \times 10^{5}$. Labeled DNA fragments were denatured by boiling for $4 \mathrm{~min}$, rapidly cooled to $60^{\circ} \mathrm{C}$, purified further by passage through a hydroxyapatite (HA) column equilibrated with $0.14 \mathrm{M}$ phosphate buffer (PB; equimolar mixture of $\mathrm{NaH}_{2} \mathrm{PO}_{4}$ and $\mathrm{Na}_{2} \mathrm{HPO}_{4}, \mathrm{pH} 6.8$ ) plus $0.4 \%$ sodium dodecyl sulfate (SDS), and held at $60^{\circ} \mathrm{C}$. Any labeled material bound to the column under these conditions was discarded. This procedure removes cross-linked DNA and other contaminating material that retains the ability to bind to $\mathrm{HA}$ after boiling and quick coolling. After this procedure, the zero-time binding (label bound to HA immediately after DNA is denatured) is usually less than $3 \%$. In these experiments, the specific activity of labeled DNA was $2.5 \times$ $10^{4}$ to $1 \times 10^{5} \mathrm{cpm} / \mu \mathrm{g}$.

DNA reassociation. Labeled DNA fragments at a concentration of $0.1 \mu \mathrm{g} / \mathrm{ml}(2,500$ to $10,000 \mathrm{cpm} / \mathrm{ml})$ plus $150 \mu \mathrm{g}$ of unlabeled DNA fragments per ml contained in $0.28 \mathrm{M} \mathrm{PB}$ were thermally denatured, quickly cooled, and then incubated at either 60 or $75^{\circ} \mathrm{C}$ for 16 $h$ to reach an approximate $\mathrm{C}_{0} \mathrm{t}$ of 100 (DNA concentration $\times$ time units; reference 4) for the unlabeled DNA. After incubation, the PB was diluted to a concentration of $0.14 \mathrm{M}$, and the mixture was applied to
HA to separate single-stranded DNA from reassociated DNA. HA was equilibrated with $0.14 \mathrm{M}$ PB plus $0.4 \%$ SDS and held at the temperature at which the DNA reassociation reaction had been carried out $(60$ or $75^{\circ} \mathrm{C}$ ).

In 0.14 M PB, single-stranded DNA does not bind to $\mathrm{HA}$, whereas double-stranded DNA is adsorbed to HA. Four 15-ml portions of $0.14 \mathrm{M}$ PB plus $0.4 \%$ SDS at the incubation temperature removed unreacted DNA. The HA was then treated with either four 15$\mathrm{ml}$ portions of $0.4 \mathrm{M} \mathrm{PB}$ (at which salt concentration double-stranded DNA is eluted from HA) or in a series of $15-\mathrm{ml}$ portions of $0.14 \mathrm{M}$ PB buffer at increasing $5^{\circ} \mathrm{C}$ increments up to $100^{\circ} \mathrm{C}$ (when thermal stability of reassociated DNA was of interest). As the incubation temperature exceeds the $T_{m(e)}$ (the temperature at which $50 \%$ of the DNA bound to HA is denatured) of various stability classes of DNA, the resulting single-stranded fragments are eluted from $\mathrm{HA}$, and a thermal elution profile is obtained. The HA was finally washed with one $15-\mathrm{ml}$ portion of $0.4 \mathrm{M}$ PB to elute any material that remained bound to $\mathrm{HA}$. All eluates were collected in counting vials and assayed directly by Cerenkov radiation in a scintillation counter (6). In control experiments, the reassociation of labeled DNA in $0.28 \mathrm{M}$ PB was less than $1 \%$. Relative binding values were not corrected for the background reassociation of labeled DNA.

DNA relatedness is the amount of labeled DNA reassociation in a reaction between labeled and unlabeled DNA (heterologous reaction) relative to the amount of labeled DNA reassociation in a homologous reaction where labeled and unlabeled DNA are from the same source. Relatedness is expressed in percent. Percent relatedness may be conveniently expressed as relative binding ratio (RBR). The equation used is: $\mathrm{RBR}=\%$ relatedness $=[(\%$ heterologous DNA bound to $\mathrm{HA}) /(\%$ homologous DNA bound to HA) $] \times 100$. Relatedness is arbitrarily deemed to be close or high ( $\mathrm{RBR}=65 \%$ or more), moderate $(\mathrm{RBR}=25$ to $60 \%)$, or distant $(\mathrm{RBR}=$ less than $25 \%)$. Percent divergence $(D)$ is calculated on the assumption that a $1^{\circ} \mathrm{C}$ decrease in thermal stability of a DNA duplex is caused by each $1 \%$ of unpaired bases within that duplex (28). For example, consider organisms A and B that are 50\% related. An A-A duplex has a mean thermal stability of $91^{\circ} \mathrm{C}$, whereas an A-B duplex has a mean thermal stability of $81^{\circ} \mathrm{C}$. The $D$ in related DNA is $10 \%$.

Glossaries of DNA association terms helpful to the nonspecialist are given in references 3 and 42 .

The amount of reassociation obtained in homologous control reactions, the thermal stability of these DNA duplexes, and the amount of reassociation of controls containing labeled DNA only are shown in Table 2.

\section{RESULTS}

Relatedness of protei to other Enterobacteriaceae. There has not been a thorough study of the relatedness of protei to other Enterobacteriaceae. These relationships were determined by labeling DNA from one or more strains of each species of Proteus and Providencia and reacting these preparations with DNA from 
TABLE 1. Bacterial strains used

Bacillus subtilis 168

Citrobacter freundii $80-68$

Edwardsiella tarda 1483-59

Enterobacter aerogenes 1627-66

Enterobacter agglomerans 1645-71

Enterobacter agglomerans 19321

Enterobacter cloacae 1347-71

Enterobacter cloacae 4562-70

Erwinia amylovora EA 178

Erwinia quercina EQ 102

Erwinia salicis 15712

Escherichia coli $\mathrm{K}-12$

Hafnia alvei (Enterobacter hafniae) 962-68

Klebsiella pneumoniae 2

Pectobacterium carotovorum 495

Pectobacterium chrysanthemi SR 32

Pectobacterium cypripedii EC 155

Proteus mirabilis (americanus) 4675

$P$. mirabilis 1

P. mirabilis PR 11

P. mirabilis $\mathrm{PR} 14$

P. mirabilis $\mathrm{PR} 22$

$P$. mirabilis $\mathrm{PR} 23 \mathrm{~K}$

P. mirabilis $\mathrm{PR} 25$

P. mirabilis 82-73

$P$. mirabilis 412-66

P. mirabilis 1140-73

P. mirabilis $1788-72$

P. mirabilis 1922-73

P. mirabilis 2098-73

$P$. mirabilis 2113-72

P. mirabilis 14253

Proteus mitajiri 21136

Proteus morganii

P. morganii 102

P. morganii 105-52

P. morganii 141-49

P. morganii 1166-73

P. morganii 1167

P. morganii 1255-73

P. morganii 1422-73

P. morganii 1640-73

P. morganii 1881-73 Atypical ${ }^{\alpha}$ biochemical reactions

\section{J. Marmur}

$\mathrm{CDC}^{b}$

CDC

CDC

CDC

ATCC $^{c}$

CDC

CDC

$\mathrm{ICPB}^{d}$

ICPB

ATCC

U. Washington

CDC

CDC

ATCC

A. Kelman

ICPB

ATCC

S. Falkow

CDC

CDC

CDC

CDC

CDC

CDC

$\mathrm{Lac}^{+}$Ind $^{+}$

CDC

CDC

Ind ${ }^{+}$

CDC

CDC

$\mathrm{PPA}^{-}$

Ure

CDC

CDC

ATCC

ATCC

S. Falkow

CDC

CDC

$\mathrm{CDC}$

CDC

$\mathrm{CDC}$

$\mathrm{CDC}$

CDC

$\mathrm{Orn}^{-}$ 
TABLE 1-Continued

\begin{tabular}{|c|c|c|}
\hline Strain & Atypical $^{\alpha}$ biochemical reactions & Source \\
\hline P. morganii $2698-75$ & $\mathrm{Orn}^{-}$ & CDC \\
\hline P. morganii 3205-70 & $\mathrm{Orn}^{-}$ & $\mathrm{CDC}$ \\
\hline P. morganii $3483-75$ & $\mathrm{Orn}^{-}$ & CDC \\
\hline P. morganii $5832-72$ & Ind $^{-}$ & $\mathrm{CDC}$ \\
\hline P. morganii 5946-71 & Ind $^{-}$PPA $^{-}$ & CDC \\
\hline P. morganii $6166-50$ & & CDC \\
\hline P. morganii $9027-75$ & & CDC \\
\hline P. morganii 25830 & & ATCC \\
\hline P. morganii $73-011043$ & Orn $^{-}$ & CDC \\
\hline
\end{tabular}

Proteus myxofaciens 19692.

Proteus rettgeri BG 5b 285-75 .

$\begin{array}{ll} & \text { ATCC } \\ \mathrm{Lac}^{+} & \text {CDC } \\ \mathrm{Lac}^{+} & \text {CDC } \\ \text { Ind }^{-} \mathrm{Lac}^{+} & \text {CDC } \\ \mathrm{Rha}^{-} & \text {CDC } \\ \mathrm{Lac}^{+} & \text {CDC } \\ & \text { CDC } \\ \text { Ino }^{-} \mathrm{Cit}^{-} & \text {CDC } \\ & \text { CDC } \\ \mathrm{Ure}^{-} \mathrm{Cit}^{-} & \text {CDC } \\ \mathrm{Cit}^{-} \mathrm{Ino}^{-} & \text {CDC } \\ & \text { CDC } \\ \text { Ind }^{-} & \text {CDC } \\ & \text { CDC } \\ \text { Ind }^{-} \mathrm{Ado}^{-} \mathrm{Ery}^{-} \mathrm{Rha}^{-} \mathrm{Tar}^{-} & \text {CDC } \\ \mathrm{Mot}^{-} \mathrm{Gas}^{+} \mathrm{Lac}^{+} \mathrm{Suc}^{+} \mathrm{Raf}^{+} & \text {CDC } \\ \text { Tar }^{-} & \text {CDC } \\ & \text { CDC } \\ \mathrm{PPA}^{-} & \text {CDC } \\ \mathrm{Lac}^{+} & \text {CDC } \\ \text { Ind }^{-} & \text {CDC } \\ & \text { CDC } \\ & \text { ATCC } \\ & \text { A Sonnenwirth }\end{array}$

P. rettgeri $\mathrm{BG}$ 5b 286-75

$P$. rettgeri $\mathrm{BG} 5 \mathrm{~b} 416-72$

$P$. rettgeri $\mathrm{BG}$ 1a $666-48$

$P$. rettgeri BG 5b 697-75

$P$. rettgeri $\mathrm{BG} 2 \mathrm{~b} 1163$

P. rettgeri $\mathrm{BG}$ 3a 1165

P. rettgeri $\mathrm{BG}$ 1b 1226-73

$P$. rettgeri $\mathrm{BG} 2 \mathrm{a} 1266$

$P$. rettgeri $\mathrm{BG}$ 1a $1387-73$

$P$. rettgeri $\mathrm{BG}$ 3a $1519-73$

P. rettgeri $\mathrm{BG}$ 5b 1586-76

P. rettgeri BG 5b 1631-75

$P$. rettgeri $\mathrm{BG}$ 3a $3737-74$

P. rettgeri $\mathrm{BG}$ 5b 3899-72

P. rettgeri BG 5b 4100-74

P. rettgeri 4709-72

P. rettgeri 1a 4884-72

P. rettgeri $\mathrm{BG}$ 3a 4926-50

$P$. rettgeri $\mathrm{BG}$ 3a 5364-72

$P$. rettgeri $\mathrm{BG} 5 \mathrm{~b}$ 5833-72

P. rettgeri $\mathrm{BG}$ 5b 6281-73

$P$. rettgeri BG 1a 9250

$P$. rettgeri BG 5b 15267

Ind $^{-}$

A. Sonnenwirth

Proteus sphingidis 6911

Proteus vulgaris PR1

$P$. vulgaris PR3

P. vulgaris $\mathrm{PR} 7$

P. vulgaris $\mathrm{PR} 10$

P. vulgaris $\mathrm{PR} 19$

P. vulgaris 169

$P$. vulgaris $636-73$

$P$. vulgaris $645-72$

$P$. vulgaris $931-72$

P. vulgaris $1070-73$

P. vulgaris $1608-73$

P. vulgaris $1808-73$

P. vulgaris (paraamericanus) 6059

Ure
$\mathrm{H}_{2} \mathrm{~S}^{-}$Ind $^{-}$
$\mathrm{Nit}^{-} \mathrm{H}_{2} \mathrm{~S}^{-}$
Ind $^{-}$

ATCC

CDC

CDC

CDC

CDC

CDC

CDC

CDC

CDC

CDC

CDC

CDC

Providencia alcalifaciens BG 1 671-66

CDC

$P$. alcalifaciens BG 1 1045-67

$P$. alcalifaciens BG 1 1805-66

P. alcalifaciens BG 1 1915-67

$P$. alcalifaciens BG 1 2424-66

$P$. alcalifaciens BG 1 3013-68

$P$. alcalifaciens BG $13055-67$

$P$. alcalifaciens BG 14077-67

$P$. alcalifaciens BG 1 4673-67

ATCC

CDC

CDC

CDC

CDC

CDC

CDC

CDC

CDC

CDC 
TABLE 1-Continued

\begin{tabular}{|c|c|c|}
\hline Strain & Atypical $^{a}$ biochemical reactions & Source \\
\hline 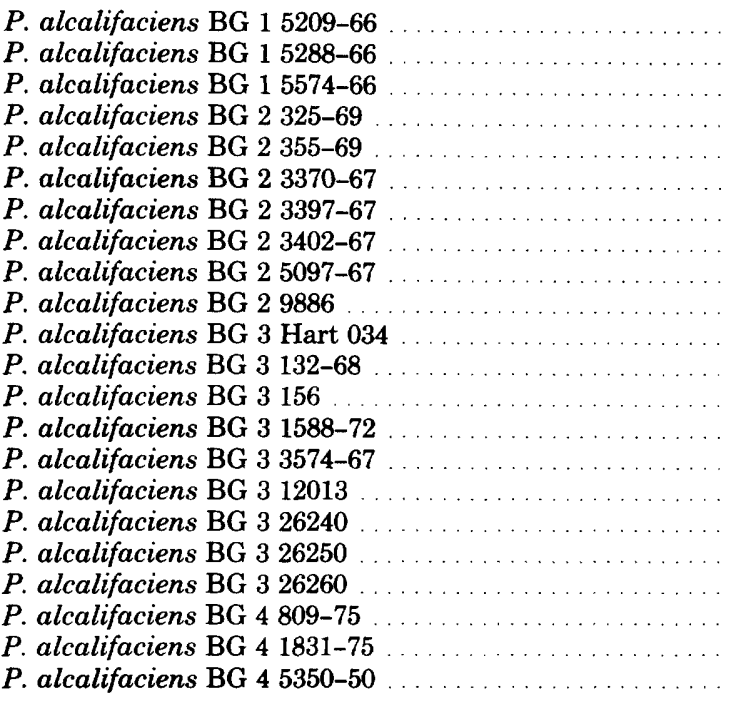 & Ind $^{-}$ & $\begin{array}{l}\text { CDC } \\
\text { CDC } \\
\text { CDC } \\
\text { CDC } \\
\text { CDC } \\
\text { CDC } \\
\text { CDC } \\
\text { CDC } \\
\text { ATCC } \\
\text { CDC } \\
\text { CDC } \\
\text { CDC } \\
\text { CDC } \\
\text { CDC } \\
\text { ATCC } \\
\text { CDC } \\
\text { CDC } \\
\text { CDC } \\
\text { CDC } \\
\text { CDC } \\
\text { CDC }\end{array}$ \\
\hline 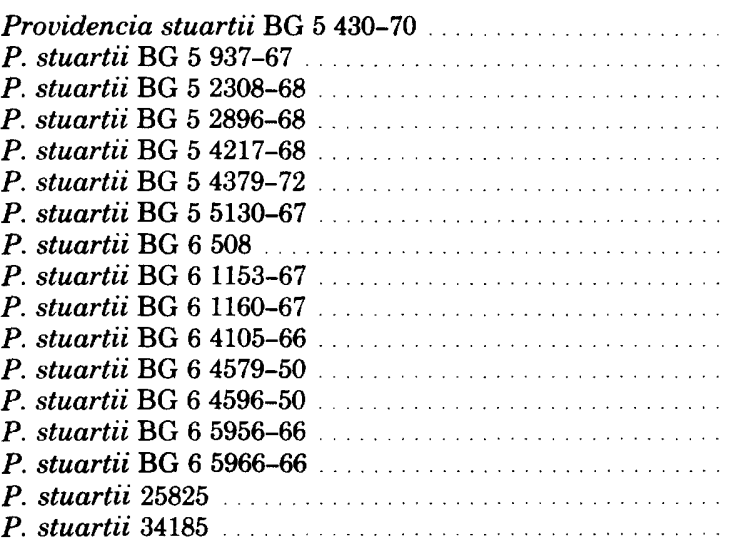 & $\mathrm{PPA}^{-}$ & $\begin{array}{l}\text { CDC } \\
\text { CDC } \\
\text { CDC } \\
\text { CDC } \\
\text { CDC } \\
\text { CDC } \\
\text { CDC } \\
\text { CDC } \\
\text { CDC } \\
\text { CDC } \\
\text { CDC } \\
\text { CDC } \\
\text { CDC } \\
\text { CDC } \\
\text { CDC } \\
\text { CDC } \\
\text { CDC }\end{array}$ \\
\hline
\end{tabular}

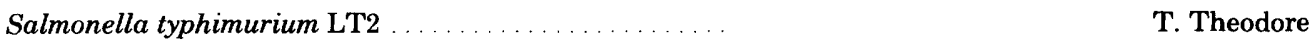

Serratia liquefaciens $446-68 \ldots \ldots \ldots \ldots \ldots \ldots \ldots \ldots$

Serratia marcescens SM6 ................... WRAIR

Serratia rubidaea $\mathbf{9 3 4 - 7 2 \ldots \ldots \ldots \ldots \ldots \ldots \ldots \ldots \ldots . \ldots . \ldots 2}$

Shigella flexneri $24570 \ldots \ldots \ldots \ldots \ldots \ldots \ldots \ldots \ldots \ldots$

Yersinia enterocolitica $497-70 \ldots \ldots \ldots \ldots \ldots \ldots \ldots$ CDC

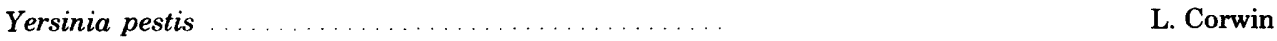

${ }^{a}$ Abbreviations for biochemical reactions: Lac, lactose; Ind, indole; Ure, urease; Orn, ornithine; Ino, inositol; Gas, gas from glucose; Nit, nitrate reduction; Cit, Simmons citrate; PPA, phenylalanine deaminase; Mot ${ }^{-}$, nonmotile; Tar, Jordan's tartrate; Suc, sucrose; Raf, raffinose; Rha, L-rhamnose; Ado, adonitol; Ery, erythritol.

${ }^{b}$ Center for Disease Control, Atlanta, Ga.

' American Type Culture Collection, Rockville, Md.

${ }^{d}$ International Collection of Phytopathogenic Bacteria, Davis, Calif.

${ }^{e}$ Walter Reed Army Institute of Research, Washington, D.C. 
TABLE 2. Homologous DNA reactions ${ }^{a}$

\begin{tabular}{cccc}
\hline Source of $\mathrm{DNA}^{b}$ & $\begin{array}{c}60^{\circ} \mathrm{C} \\
\text { RBR }\end{array}$ & $T_{m(e)}$ & $\begin{array}{c}75^{\circ} \mathrm{C} \\
\text { RBR }\end{array}$ \\
\hline Proteus mirabilis PR 14 $\ldots \ldots$ & 80 & 88 & 74 \\
P. mirabilis PR 14 label only $\ldots$ & 3.7 & & 1.7
\end{tabular}

\begin{tabular}{|c|c|c|c|}
\hline $\begin{array}{l}\text { Proteus morganii } 25830 \ldots \ldots \\
\text { P. morganii } 25830 \text { label only }\end{array}$ & $\begin{array}{l}90 \\
1.4\end{array}$ & 92 & $\begin{array}{l}89 \\
1.8\end{array}$ \\
\hline $\begin{array}{l}\text { Proteus rettgeri } 1163 \ldots \ldots \\
\text { P. rettgeri } 1163 \text { label only } \ldots\end{array}$ & $\begin{array}{l}87 \\
2.3\end{array}$ & 89 & $\begin{array}{l}80 \\
2.0\end{array}$ \\
\hline $\begin{array}{l}\text { Proteus rettgeri } 3899-72 \ldots \\
P \text {. rettgeri } 3899-72 \text { label only }\end{array}$ & $\begin{array}{c}83 \\
3.2\end{array}$ & 89 & $\begin{array}{l}78 \\
2.6\end{array}$ \\
\hline $\begin{array}{l}\text { Proteus rettgeri } 9250 \ldots \ldots \\
P . \text { rettgeri } 9250 \text { label only }\end{array}$ & $\begin{array}{l}87 \\
3.6\end{array}$ & 89 & $\begin{array}{l}80 \\
2.9\end{array}$ \\
\hline $\begin{array}{l}\text { Proteus vulgaris } \mathrm{PR} 1 \\
\text { P. vulgaris } \mathrm{PR} 1 \text { label only }\end{array}$ & $\begin{array}{l}83 \\
1.4\end{array}$ & 88 & $\begin{array}{l}75 \\
1.4\end{array}$ \\
\hline $\begin{array}{l}\text { Proteus vulgaris } 13315 \ldots \\
\text { P. vulgaris } 13315 \text { label only }\end{array}$ & $\begin{array}{c}67 \\
1.4\end{array}$ & 88 & $\begin{array}{l}65 \\
3.8\end{array}$ \\
\hline $\begin{array}{l}\text { Providencia alcalifaciens } \\
\quad 3370-67 \ldots \ldots \\
P . \text { alcalifaciens } 3370-67 \text { label } \\
\text { only } \ldots \ldots \ldots\end{array}$ & $\begin{array}{l}85 \\
2.3\end{array}$ & 89 & 80 \\
\hline $\begin{array}{l}\text { Providencia alcalifaciens } \\
\quad 132-68 \ldots \ldots \ldots \\
P . \text { alcalifaciens } 132-68 \text { label } \\
\text { only } \ldots \ldots \ldots \ldots \ldots\end{array}$ & 53 & 88 & 39 \\
\hline $\begin{array}{l}\text { Providencia alcalifaciens } \\
\quad 2617-71 \ldots \\
P . \text { alcalifaciens } 2617-71 \text { label } \\
\text { only }\end{array}$ & 87 & 89 & 78 \\
\hline $\begin{array}{l}\text { Providencia stuartii } 2896-68 \\
\text { P. stuartii } 2896-68 \text { label only }\end{array}$ & $\begin{array}{l}80 \\
3.4\end{array}$ & 89 & $\begin{array}{c}72 \\
2.4\end{array}$ \\
\hline $\begin{array}{l}\text { Providencia stuartii } 3233-68 \\
P . \text { stuartii } 3233-68 \text { label only }\end{array}$ & $\begin{array}{c}80 \\
2.6\end{array}$ & & \\
\hline
\end{tabular}

\footnotetext{
${ }^{a}$ Abbreviations: RBR, relative binding ratio; $T_{m(e)}$, thermal elution midpoint.

${ }^{b}$ For each pair, the upper reaction contained $0.1 \mu \mathrm{g}$ of labeled DNA plus $150 \mu \mathrm{g}$ of unlabeled DNA, and the lower reaction contained $0.1 \mu \mathrm{g}$ of labeled DNA in the absence of unlabeled DNA. The numbers shown are the arithmetic means of 10 or more reactions.
}

most species of Enterobacteriaceae. Prot. morganii was about $20 \%$ related to species other than protei (Table 3). All other species of Proteus and Providencia had an average of 6 to $13 \%$ relatedness to species other than protei (Table 3). In $75^{\circ} \mathrm{C}$ reactions, the relatedness of Prot. morganii to other Enterobacteriaceae fell to $5 \%$ or less, and that of other protei to other Enter. obacteriaceae fell to between 0 and $2 \%$.

Prot. mirabilis and Prot. vulgaris. All of the DNA relatedness data for the protei in this study are shown in Table 4. For convenience, summary tables have also been included for specific groups (Tables 5 to 11). Prot. mirabilis strains were $90 \%$ related with very little divergence within the reassociated sequences (Table 5). Prot. mirabilis was $55 \%$ related to Prot. vulgaris. The related sequences showed $12 \% \mathrm{D}$, and relatedness in $75^{\circ} \mathrm{C}$ reactions was $20 \%$. Prot. mirabilis was less than $25 \%$ related to other Proteus and Providencia species.

Strains of Prot. vulgaris formed more than one DNA relatedness group (Table 6). Six strains were extremely closely related $(94 \%)$ to reference strain PR1. Five other strains (931-72 group) were $70 \%$ related to $P R 1$ with an average $7 \% \mathrm{D}$. The average reaction at $75^{\circ} \mathrm{C}$ of $\mathrm{PR} 1$ with these strains was $34 \%$. Prot. myxofaciens was about $45 \%$ related to both Prot. mirabilis and Prot. vulgaris PR1.

The relatedness of Prot. vulgaris PR1 and Prot. vulgaris 13315 to other Proteus and Providencia species was 15 to $20 \%$ (Table 6).

Prot. morganii. All tested strains of Prot. morganii were in one DNA relatedness group. The average relatedness was $90 \%$ in $60^{\circ} \mathrm{C}$ reactions and $85 \%$ in $75^{\circ} \mathrm{C}$ reactions (Table 7 ). The related sequences contained less than $1 \%$ unpaired bases. Prot. morganii was less than $20 \%$ related to all other protei in $60^{\circ} \mathrm{C}$ reactions and less than $5 \%$ related to them in $75^{\circ} \mathrm{C}$ reactions.

Prot. rettgeri, Prov. alcalifaciens, and Prov. stuartii. Prot. rettgeri strains form three DNA relatedness groups. The Prot. rettgeri 1163 group is composed of strains that are mainly biochemically typical and belong to Penner's BG 1,2 , and $3(34)$. These strains were $79 \%$ related and showed an average $D$ of $3 \%$ (Tables 4 and 8). The average relatedness at $75^{\circ} \mathrm{C}$ was $63 \%$ (Table 8).

The $1163^{-}$group was about $20 \%$ related to other Proteus species and 35 to $40 \%$ related to Providencia species. Almost identical results were obtained (not shown) when we used labeled DNA from another member of the 1163 group (strain 9250).

All members of a second group of Prot. rettgeri strains, exemplified by strain 3899-72, are in the Penner BG 5b (34). This group was inseparable from Prot. stuartii on the basis of DNA reassociation (Tables 4 and 8 ). The 3899-72 group was 30 to $35 \%$ related to typical Prot. rettgeri and to Prov. alcalifaciens (Table 8 ) and 16 to $25 \%$ related to other Proteus species (Tables 4 to 8 ).

The third Prot. rettgeri relatedness group (666-48 group) is composed of five strains that are biochemically atypical. They were most closely related to Prot. rettgeri and Providencia species (30 to $45 \%$, Tables 4 to 11 ). These strains did not appear to form a single group on the 
TABLE 3. DNA relatedness of members of the tribe Proteeae to other Enterobacteriaceae

\begin{tabular}{|c|c|c|c|c|c|c|c|c|c|}
\hline \multirow[b]{2}{*}{ Source of unlabeled DNA } & \multicolumn{9}{|c|}{$\mathrm{RBR}^{a}, 60^{\circ} \mathrm{C}$} \\
\hline & $\begin{array}{c}\text { Prot. } \\
\text { mirabi- } \\
\text { lis } \\
\text { PR } 14\end{array}$ & $\begin{array}{l}\text { Prot. } \\
\text { rettgeri } \\
1163\end{array}$ & $\begin{array}{c}\text { Prot. } \\
\text { rettgeri } \\
9250\end{array}$ & $\begin{array}{c}\text { Prot. } \\
\text { rettgeri } \\
3899-72\end{array}$ & $\begin{array}{c}\text { Prot. } \\
\text { vul- } \\
\text { garis } \\
\text { PR 1 }\end{array}$ & $\begin{array}{c}\text { Prov. } \\
\text { alcali- } \\
\text { faciens } \\
\text { BG 2 } \\
3370-67\end{array}$ & $\begin{array}{c}\text { Prov. } \\
\text { stuartii } \\
\text { BG 5 } \\
2896-68\end{array}$ & $\begin{array}{c}\text { Prov. } \\
\text { stuartii } \\
\text { BG } 6 \\
3233-68\end{array}$ & $\begin{array}{l}\text { Prot. } \\
\text { mor- } \\
\text { ganii } \\
25830\end{array}$ \\
\hline Citrobacter freundii $80-68$ & 11 & 10 & & & 8 & 12 & & & 20 \\
\hline Edwardsiella tarda 1483-59 & 10 & 10 & 6 & 4 & 7 & 11 & 6 & 5 & 22 \\
\hline Enterobacter aerogenes 1627-66 & 12 & 10 & & & 7 & & & & 21 \\
\hline \multicolumn{10}{|l|}{ Enterobacter agglomerans } \\
\hline $1645-71 \ldots \ldots \ldots$ & 10 & 10 & & & & 12 & & & 19 \\
\hline Enterobacter agglomerans 19321 & 10 & 9 & & & 7 & & & & 19 \\
\hline Enterobacter cloacae $1347-71 \ldots$ & 10 & 11 & & & 7 & 13 & & & 21 \\
\hline Enterobacter cloacae $4562-70 \ldots$ & 11 & 11 & & & & 12 & & & 23 \\
\hline Enterobacter hafniae .......... & 13 & 15 & 9 & 9 & 11 & 15 & 9 & 9 & 20 \\
\hline Erwinia amylovora EA $178 \ldots \ldots$ & 10 & 10 & & & 7 & 11 & & & 18 \\
\hline Erwinia quercina EQ $102 \ldots \ldots$ & 10 & 10 & & & & & & & 19 \\
\hline Erwinia salicis $15712 \ldots \ldots \ldots$ & 11 & 10 & & & & 12 & & & 20 \\
\hline Escherichia coli $\mathrm{K}-12 \ldots$ & 12 & 12 & 8 & 9 & 8 & 13 & 5 & 8 & 24 \\
\hline Klebsiella pneumoniae 2 & 11 & 8 & 5 & 5 & & 12 & 5 & 6 & 23 \\
\hline $\begin{array}{l}\text { Pectobacterium carotovorum } 495 \\
\text { Pectobacterium chrysanthemi } \mathrm{SR}\end{array}$ & 12 & 11 & & & 9 & 16 & & & 21 \\
\hline $32 \ldots \ldots$ & 14 & 7 & & & & & & & 18 \\
\hline Pectobacterium cypripedii EC 155 & 13 & 9 & & & & & & & 22 \\
\hline Salmonella typhimurium LT2 ... & 12 & 11 & 8 & 8 & 9 & 13 & 6 & 6 & 22 \\
\hline Serratia liquefaciens $446-68 \ldots \ldots$ & 11 & 11 & & & & & & & 22 \\
\hline Serratia marcescens SM6 & 11 & 10 & 5 & 6 & 6 & 11 & & 6 & 24 \\
\hline Serratia rubidaea $934-72$ & 10 & 10 & & & & & & & 20 \\
\hline Shigella flexneri 24570 & 14 & 10 & & & & & & & 23 \\
\hline Yersinia enterocolitica $497-70 \ldots$ & 16 & 14 & & & 11 & 16 & & & 18 \\
\hline Yersinia pestis $\ldots \ldots \ldots \ldots \ldots$ & $\underline{13}$ & & & & & & & & 15 \\
\hline Average $\quad \ldots \ldots \ldots \ldots \ldots \ldots$ & $\overline{12}$ & $\overline{10}$ & $\overrightarrow{7}$ & $\overline{7}$ & $\overline{8}$ & $\overline{13}$ & $\overline{6}$ & $\overline{7}$ & 21 \\
\hline Bacillus subtilis 168 & 0 & 0.5 & & & 0.5 & & & & 2 \\
\hline
\end{tabular}

${ }^{a}$ RBR, Relative binding ratio. See Materials and Methods for definition.

basis of biochemical profiles (Table 1). No strains from this group were labeled for use as reference strains in hybridization studies. It is therefore possible that they belong to two or more hybridization groups.

Prov. alcalifaciens BG 1 and 2 strains were in one hybridization group with $89 \%$ average relatedness and $3 \% D$ at $60^{\circ} \mathrm{C}$, and $74 \%$ average relatedness at $75^{\circ} \mathrm{C}$ (Table 9). Seven BG 1 strains and seven BG 2 strains were 90 to $100 \%$ related at both incubation temperatures and exhibited less than $1 \% D$. Five additional BG 1 strains were 75 to $80 \%$ related to the reference $B$ 2 strain (3370-67). In these reactions, $D$ was 5 to $10 \%$, and relatedness fell to between 41 and $60 \%$ in $75^{\circ} \mathrm{C}$ reactions. This level of relatedness implies divergence within strains of a single species that is not yet sufficient for the formation of two species. Prov. alcalifaciens BG 3 strains are 55\% related to BG 1 and 2. Prov. stuartii and the three Prot. rettgeri groups are 35 to $48 \%$ related to BG 1 and 2. Relatedness of other Proteus species to BG 1 and 2 is $20 \%$.

Prov. alcalifaciens BG 3 strains were all closely related (Table 10 ). They were $45 \%$ related to Prov. alcalifaciens BG 1 and 2, 25 to $30 \%$ related to Prov. stuartii and the three Prot. rettgeri groups, and 10 to $15 \%$ related to other Proteus species.

All Prov. stuartii strains and the BG 5 strains of Prot. rettgeri (the 3899-72 group) were $90 \%$ related (Table 11). The other Prot. rettgeri groups and Prov. alcalifaciens groups were 35 to $40 \%$ related to Prov. stuartii. Proteus species were 14 to $29 \%$ related to Prov. stuartii.

There is a BG 4 in Prov. alcalifaciens. Several strains presumed to belong to $\mathrm{BG} 4$ were indistinguishable from Prov. stuartii in DNA hybridization reactions. These strains were reexamined and shown to be inositol-positive, typical strains of Prov. stuartii (Table 12). DNA from three strains with the biochemical characteristics of Prov. alcalifaciens BG 4 were subsequently tested for relatedness to $\left[{ }^{3} \mathrm{H}\right] \mathrm{DNA}$ of Prov. stuartii at the stringent $75^{\circ} \mathrm{C}$ incubation temperature. The RBR values obtained were 89,88 , and $75 \%$. RBR values at $75^{\circ} \mathrm{C}$ with these strains and Prov. alcalifaciens BG 1,2,3, and Proteus 


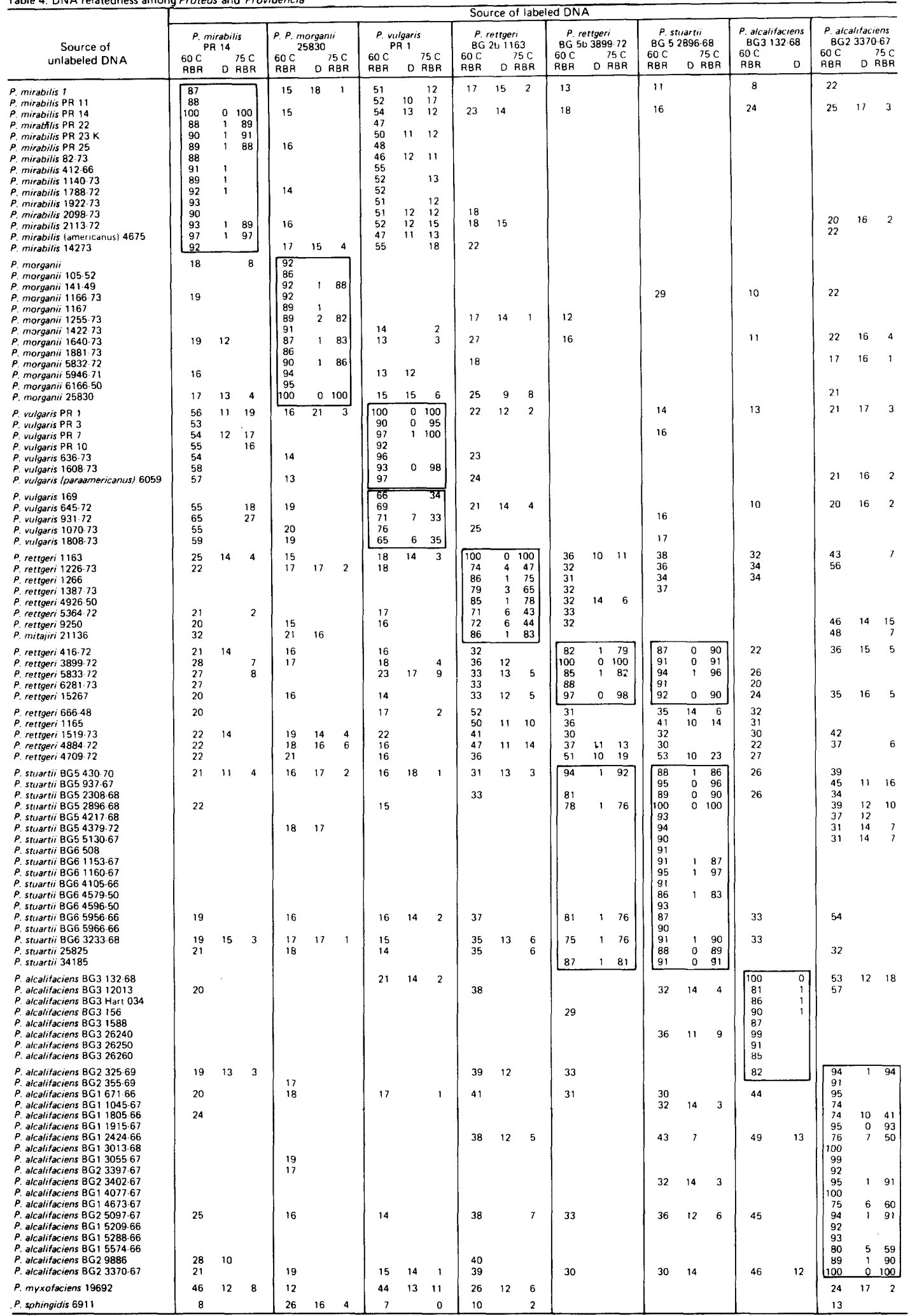


TABLE 5. DNA relatedness of Proteeae to Proteus mirabilis PR14

\begin{tabular}{|c|c|c|c|c|}
\hline Source of unlabeled DNA & $\begin{array}{c}\text { No. of } \\
\text { strains }\end{array}$ & $\begin{array}{l}60^{\circ} \mathrm{C} \\
\mathrm{RBR}^{b}\end{array}$ & $D$ & $\begin{array}{l}75^{\circ} \mathrm{C} \\
\mathrm{RBR}\end{array}$ \\
\hline Prot. mirabilis & 14 & 91 & $<1$ & 91 \\
\hline $\begin{array}{l}\text { Prot. vulgaris } \ldots \ldots \\
\text { Prot. rettgeri }\end{array}$ & 13 & 56 & 12 & 20 \\
\hline $\begin{array}{l}\text { group } \\
\text { Prot. rettgeri } 666-48\end{array}$ & 5 & 24 & 14 & 3 \\
\hline $\begin{array}{l}\text { group } \ldots \\
\text { Prot. rettgeri } 3899-72\end{array}$ & 4 & 22 & 14 & 8 \\
\hline group ............. & 5 & 25 & 14 & \\
\hline $\begin{array}{l}\text { Prot. morganii } \\
\text { Prov. alcalifaciens BG }\end{array}$ & 5 & 18 & 12 & 6 \\
\hline $\begin{array}{c}1,2 \\
\text { Prov. alcalifaciens } \mathrm{BG}\end{array}$ & 6 & 23 & 12 & 3 \\
\hline $3 \ldots \ldots \ldots \ldots$ & 1 & 20 & & \\
\hline Prov. stuartii & 5 & 20 & 13 & 4 \\
\hline Prot. myxofaciens & 1 & 46 & 12 & 8 \\
\hline
\end{tabular}

${ }^{a}$ Number of strains tested in $60^{\circ} \mathrm{C}$ reactions. Fewer strains were tested for $D$ (percent divergence) and for relatedness at $75^{\circ} \mathrm{C}$ (see Table 4). The homologous control reaction ( $100 \%$ by definition) is not included in the number of strains tested or in the calculations of $\mathrm{RBR}$ and $D$.

${ }^{b}$ Relative binding ratio (RBR) values are arithmetic means obtained from the total number of strains tested. Relatedness values for individual strains are given in Table 4.

TABle 6. DNA relatedness of Proteeae to Proteus vulgaris $P R 1^{a}$

\begin{tabular}{|c|c|c|c|c|}
\hline Source of unlabeled DNA & $\begin{array}{l}\text { No. of } \\
\text { strains }\end{array}$ & $\begin{array}{l}60^{\circ} \mathrm{C} \\
\mathrm{RBR}\end{array}$ & $D$ & $\begin{array}{l}75^{\circ} \mathrm{C} \\
\mathrm{RBR}\end{array}$ \\
\hline $\begin{array}{c}\text { Prot. vulgaris } \text { PR1 } \\
\text { group }\end{array}$ & 6 & 94 & $<1$ & 98 \\
\hline $\begin{array}{l}\text { Prot. vulgaris } 931-72 \\
\text { group }\end{array}$ & 5 & 69 & 7 & 34 \\
\hline Prot mirabilis $\ldots \ldots$ & 15 & 51 & 12 & 13 \\
\hline $\begin{array}{l}\text { Prot. rettgeri } 1163 \\
\text { group } \ldots \ldots\end{array}$ & 4 & 17 & & \\
\hline $\begin{array}{l}\text { Prot. rettgeri } 666-48 \\
\text { group } \ldots \ldots \ldots \ldots \ldots \\
\text { Prot rettgeri } 3899-72\end{array}$ & 4 & 18 & & 2 \\
\hline group $\ldots \ldots \ldots \ldots$ & 4 & 19 & 17 & 7 \\
\hline $\begin{array}{l}\text { Prot. morganii ... } \\
\text { Prov. alcalifaciens BG }\end{array}$ & 4 & 14 & 14 & 4 \\
\hline $\begin{array}{r}1,2 \\
\text { Prov. alcalifaciens BG }\end{array}$ & 3 & 15 & 14 & 1 \\
\hline & 1 & 21 & 14 & 2 \\
\hline Prov. stuartii & 5 & 15 & 16 & $\overline{2}$ \\
\hline Prot. myxofaciens & 1 & 44 & 13 & 11 \\
\hline
\end{tabular}

${ }^{a}$ See footnotes to Table 5.

species yielded RBR values of below $10 \%$.

Additional organisms. Several strains listed as Proteus species separate from the accepted species of Proteus, as well as varieties of accepted species, were included in this study ( $\mathrm{Ta}$ ble 4). Prot. mirabilis (Prot. americanus) is a typical Prot. mirabilis strain, Prot. vulgaris pa. raamericanus is a typical Prot. vulgaris strain, and Prot. mitajiri is a typical Prot. rettgeri (1163 group) strain. Prot. sphingidis is, as stated by the ATCC, a member of Serratia marcescens. Prot. myxofaciens does appear to represent a new species of Proteus (see section above on Prot. mirabilis and Prot. vulgaris).

\section{DISCUSSION}

Proteus and Providencia were known to be only distantly related to $E$. coli $(2,7)$. We now know that protei are distantly related to all species of Enterobacteriaceae (Table 3; D. J. Brenner, unpublished data). Species of Proteus and Providencia are biochemically and enzymatically different in many aspects and show substantial heterogeneity in DNA relatedness (7, 11; Tables 4-11).

In agreement with Kauffmann (26) and Coetzee (7), we believe that the phenotypical and genotypical divergence present in protei necessitates the establishment of additional genera. There is also a need for additional speciation in some cases and for consolidation of species in other cases. The current classification of protei and recommendations for changes in the classification and nomenclature of these organisms are summarized in Table 13. Biochemical reactions for these organisms are given in Table 14.

All Prot. mirabilis strains, including atypical $\mathrm{Lac}^{+}$, Ind ${ }^{+}$, and $\mathrm{Ure}^{-}$strains, are one genetic species. Seven strains of Prot. vulgaris (PR1 group) were $90 \%$ or more related. Five additional strains (931-72 group) were 65 to $75 \%$ related to the PR1 group. Where tested, relatedness fell to about $35 \%$ in $75^{\circ} \mathrm{C}$ reactions. Each of these

TABle 7. DNA relatedness of Proteeae to Proteus morganii $25830^{a}$

\begin{tabular}{|c|c|c|c|c|}
\hline Source of unlabeled DNA & $\begin{array}{l}\text { No. of } \\
\text { strains }\end{array}$ & $\begin{array}{l}60^{\circ} \mathrm{C} \\
\mathrm{RBR}\end{array}$ & $\boldsymbol{D}$ & $\begin{array}{l}75^{\circ} \mathrm{C} \\
\mathrm{RBR}\end{array}$ \\
\hline Prot. morganii & 12 & 90 & $<1$ & 85 \\
\hline $\begin{array}{l}\text { Prot mirabilis } \\
\text { Prot vulgaris PR1 }\end{array}$ & 6 & 16 & 17 & 3 \\
\hline $\begin{array}{c}\text { group } \\
\text { Prot. vulgaris } 931-72\end{array}$ & 3 & 14 & & \\
\hline group $\ldots \ldots \ldots$ & 3 & 19 & & \\
\hline $\begin{array}{l}\text { Prot. } \quad \text { rettgeri } 1163 \\
\text { group }\end{array}$ & 4 & 17 & 17 & 2 \\
\hline $\begin{array}{c}\text { Prot. rettgeri } 666-48 \\
\text { group }\end{array}$ & 3 & 19 & 15 & 5 \\
\hline $\begin{array}{l}\text { Prot. rettgeri } 3899-72 \\
\text { group }\end{array}$ & 3 & 16 & & \\
\hline $\begin{array}{r}\text { Prov. alcalifaciens BG } \\
1,2 \ldots\end{array}$ & 6 & 18 & & \\
\hline Prov. stuartii & 5 & 17 & 17 & 2 \\
\hline Prot. myxofaciens & 1 & 12 & & \\
\hline
\end{tabular}

${ }^{a}$ See footnotes to Table 5. 
TABle 8. DNA relatedness of Proteeae to Proteus rettgeri strains 1163 and $3899-72^{a}$

\begin{tabular}{|c|c|c|c|c|c|c|}
\hline \multirow[b]{2}{*}{ Source of unlabeled DNA } & \multicolumn{3}{|c|}{ Prot. rettgeri $\mathrm{BG} 2 \mathrm{~b} 1163^{h}$} & \multicolumn{3}{|c|}{ Prot. rettgeri BG 5b 3899-72 } \\
\hline & $\begin{array}{l}\text { No. of } \\
\text { strains }\end{array}$ & $\begin{array}{l}60^{\circ} \mathrm{C} \\
\mathrm{RBR} \\
\end{array}$ & $\begin{array}{l}75^{\circ} \mathrm{C} \\
\mathrm{RBR}\end{array}$ & $\begin{array}{l}\text { No. of } \\
\text { strains }\end{array}$ & $\begin{array}{l}60^{\circ} \mathrm{C} \\
\text { RBR } \\
\end{array}$ & $\begin{array}{l}75^{\circ} \mathrm{C} \\
\mathrm{RBR} \\
\end{array}$ \\
\hline Prot. rettgeri 1163 group & 7 & 79 & 63 & 7 & 32 & 9 \\
\hline Prot. rettgeri $3899-72$ group & 5 & 33 & 5 & 4 & 88 & 86 \\
\hline Prot. rettgeri $666-48$ group . & 5 & 45 & 12 & 5 & 37 & 16 \\
\hline Prot. mirabilis ........... & 5 & 20 & 2 & 2 & 16 & \\
\hline Prot. vulgaris $\mathrm{PRI}$ group & 3 & 23 & & & & \\
\hline Prot. vulgaris $931-72$ group & 3 & 22 & 4 & & & \\
\hline Prot. morganii ........... & 4 & 22 & 4 & & & \\
\hline Prov alcalifaciens BG $1,2 \ldots \ldots \ldots$ & 6 & 39 & 5 & 4 & 32 & \\
\hline Prov alcalifaciens BG $3 \ldots \ldots \ldots$ & 1 & 38 & & 1 & 29 & \\
\hline Prov stuartii ............. & 5 & 34 & 5 & 6 & 83 & 77 \\
\hline Prot. myxofaciens & 1 & 26 & 6 & & & \\
\hline
\end{tabular}

"For additional information, see footnotes to Table 5.

${ }^{b}$ Source of labeled DNA.

TABLE 9. DNA relatedness of Proteeae to Providencia alcalifaciens $B G 23370-67^{\circ}$

\begin{tabular}{|c|c|c|c|c|}
\hline Source of unlabeled DNA & $\begin{array}{l}\text { No. of } \\
\text { strains }\end{array}$ & $\begin{array}{l}60^{\circ} \mathrm{C} \\
\mathrm{RBR}\end{array}$ & $D$ & $\begin{array}{l}75^{\circ} \mathrm{C} \\
\mathrm{RBR}\end{array}$ \\
\hline Prov. alcalifaciens BG 1, 2 & 18 & 89 & 3 & 74 \\
\hline Prov. alcalifaciens BG 3 & 2 & 55 & 12 & 18 \\
\hline Prov, stuartii $\ldots \ldots \ldots$ & 9 & 38 & 13 & 10 \\
\hline Prot. rettgeri 1163 group .... & 4 & 48 & 14 & 10 \\
\hline Prot. rettgeri 3899-72 group & 1 & 35 & 16 & 5 \\
\hline Prot. rettgeri $666-48$ group & 2 & 40 & & 6 \\
\hline Prot. mirabilis & 4 & 22 & 17 & 3 \\
\hline Prot. vulgaris PR1 group . . . & 2 & 21 & 17 & 3 \\
\hline Prot. vulgaris $931-72$ group . & 2 & 21 & 16 & 2 \\
\hline Prot. morganii . . . . . . . . . & 4 & 21 & 16 & 3 \\
\hline Prot. myxofaciens & 1 & 24 & 17 & 2 \\
\hline
\end{tabular}

${ }^{a}$ See footnotes to Table 5 .

TABLE 10. DNA relatedness of Proteeae to Providencia alcalifaciens BG 3 132-68

\begin{tabular}{|c|c|c|}
\hline Source of unlabeled DNA & $\begin{array}{l}\text { No. of } \\
\text { strains }\end{array}$ & $\begin{array}{l}60^{\circ} \mathrm{C} \\
\text { RBR } \\
\end{array}$ \\
\hline Prov. alcalifaciens BG 3 & 8 & 88 \\
\hline Prov. alcalifaciens BG 1, 2 & 4 & 46 \\
\hline Prov. stuartii. & 4 & 30 \\
\hline Prot. rettgeri 1163 group & 3 & 33 \\
\hline Prot. rettgeri $3899-72$ group & 4 & 23 \\
\hline Prot. rettgeri $666-48$ group. & 5 & 28 \\
\hline Prot. mirabilis . . . . . . . & 1 & 16 \\
\hline Prot. vulgaris $\mathrm{PR} 1$ group & 1 & 13 \\
\hline Prot. vulgaris $931-72$ group & 2 & 10 \\
\hline Prot. morganii . . . . . . . & 2 & 11 \\
\hline
\end{tabular}

${ }^{a}$ See footnotes to Table 5.

strains exhibited higher relatedness to Prot. vulgaris than to Prot. mirabilis. Thus far, there is no known biochemical correlation with the low relatedness at $75^{\circ} \mathrm{C}$, and it is not known whether these strains belong to one or more DNA relatedness groups. Pending further study, they should remain in Prot. vulgaris.

Prot. myxofaciens was isolated from living and dead gypsy moth larvae in New York and
TABLE 11. DNA relatedness of Proteeae to Providencia stuartii BG 5 2896-68 ${ }^{a}$

\begin{tabular}{|c|c|c|c|c|}
\hline Source of unlabeled DNA & $\begin{array}{l}\text { No. of } \\
\text { strains }\end{array}$ & $\begin{array}{l}60^{\circ} \mathrm{C} \\
\mathrm{RBR}\end{array}$ & $D$ & $\begin{array}{l}75^{\circ} \mathrm{C} \\
\mathrm{RBR}\end{array}$ \\
\hline $\begin{array}{l}\text { Prov. stuartii } \ldots \ldots \ldots \\
\text { Prov. rettgeri } 3899-72\end{array}$ & 17 & 91 & $<1$ & \\
\hline $\begin{array}{l}\text { group } \\
\text { Prov. alcalifaciens BG }\end{array}$ & 5 & 91 & $<1$ & 92 \\
\hline $\begin{array}{r}1,2 \\
\text { Prov. alcalifaciens BG }\end{array}$ & 6 & 34 & 12 & 4 \\
\hline 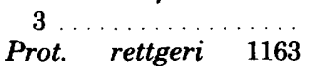 & 2 & 34 & 13 & 7 \\
\hline $\begin{array}{c}\text { group } \ldots \ldots \ldots \ldots \\
\text { Prot. rettgeri } 666-48\end{array}$ & 4 & 36 & & \\
\hline $\begin{array}{r}\text { group } \ldots \ldots \\
\text { Prot. mirabilis } \ldots \ldots \ldots\end{array}$ & $\begin{array}{l}5 \\
2\end{array}$ & $\begin{array}{l}40 \\
14\end{array}$ & 11 & 14 \\
\hline $\begin{array}{l}\text { Prot. vulgaris PR1 } \\
\text { group }\end{array}$ & 2 & 15 & & \\
\hline $\begin{array}{c}\text { Prot. vulgaris } 931-72 \\
\text { group }\end{array}$ & 3 & 16 & & \\
\hline Prot. morganii & 1 & 29 & & \\
\hline
\end{tabular}

${ }^{a}$ See footnotes to Table 5 .

TABLE 12. Biogroups of Providencia as defined by Ewing et al. ${ }^{a}$

\begin{tabular}{|c|c|c|c|}
\hline Species and biogroup & Gas & Adonitol & Inositol \\
\hline \multicolumn{4}{|l|}{ Prov alcalifaciens } \\
\hline BG 1 & + & + & - \\
\hline BG 2 & - & + & - \\
\hline BG 3 & + & - & - \\
\hline BG 4 & - & - & - \\
\hline \multicolumn{4}{|l|}{ Prov. stuartii } \\
\hline BG $5 \ldots$ & - & - & + \\
\hline BG 6 & - & + & + \\
\hline
\end{tabular}

${ }^{a}$ Reference 17.

Connecticut (10). The type strain (ATCC 19692) differed biochemically from all other protei (10). In the present study, this strain was about 50\% related to Prot. mirabilis and Prot. vul- 
TABLe 13. Classification and nomenclature of Proteeae

\begin{tabular}{|c|c|c|}
\hline Bergey's Manual (29) & DNA hybridization group & $\begin{array}{c}\text { Taxonomic proposals and recommenda- } \\
\text { tions }\end{array}$ \\
\hline Proteus mirabilis & P. mirabilis & P. mirabilis \\
\hline \multirow[t]{2}{*}{ Proteus vulgaris } & $\begin{array}{l}P . \text { vulgaris } \mathrm{PR} 1 \text { group } \\
P . \text { vulgaris } 931-72 \text { group }\end{array}$ & $\begin{array}{l}P . \text { vulgaris } \\
\text { Retain as } P \text {. vulgaris pending further } \\
\quad \text { study }\end{array}$ \\
\hline & P. myxofaciens & P. myxofaciens-a valid species \\
\hline Proteus morganii & P. morganii & Change genus name to Morganella \\
\hline Proteus rettgeri & $\begin{array}{l}\text { P. rettgeri } 1163 \text { group } \\
P \text {. rettgeri } 3899-72 \text { group BG } 5 \\
P \text {. rettgeri } 666-48 \text { group }\end{array}$ & $\begin{array}{l}\text { Transfer to Providencia } \\
\text { Transfer to Providencia stuartii, } \\
\text { urea }{ }^{+} \\
\text {Include in Providencia rettgeri pend- } \\
\text { ing further study }\end{array}$ \\
\hline $\begin{array}{l}\text { Proteus inconstans A (Providen- } \\
\quad \text { cia alcalifaciens) }\end{array}$ & $\begin{array}{l}\text { P. alcalifaciens BG } 1,2 \\
P . \text { alcalifaciens BG } 3\end{array}$ & $\begin{array}{l}\text { Providencia alcalifaciens } \\
\text { Make new species in Providencia } \\
\text { when definitive biochemical data } \\
\text { are available } \\
\text { Transfer to Providencia stuartii }\end{array}$ \\
\hline $\begin{array}{l}\text { Proteus inconstans B (Providen- } \\
\quad \text { cia stuartii) }\end{array}$ & P. stuartii BG 5, 6 & P. stuartii \\
\hline
\end{tabular}

garis. In Bergey's Manual (29), Prot. myxofaciens is reported to be identical with Erwinia herbicola (Enterobacter agglomerans). J. Leete (unpublished data) has shown that labeled Prot. myxofaciens DNA is 40 to $50 \%$ related to DNA from Prot. mirabilis and Prot. vulgaris but only about $10 \%$ related to DNA from a strain of $E$. herbicola. We conclude that Prot. myxofaciens is not a synonym of $E$. herbicola or of Prot. mirabilis (as stated in the American Type Culture Collection Catalogue, 12th ed.) but is a valid species both biochemically and genetically. The name Prot. myxofaciens has been validly published (10), and strain ATCC 19692 is the type strain for this species.

All Prot. morganii strains are highly related, including $\mathrm{Orn}^{-}$and Ind $^{-}$strains. Prot. morganii DNA contains $50 \mathrm{~mol} \% \mathrm{G}+\mathrm{C}$, which is similar to the $\mathrm{G}+\mathrm{C}$ content in $E$. coli and Salmonella rather than that of protei. It is related to most enteric bacteria at a $20 \%$ level and is not more than $20 \%$ related to other protei. For these reasons, Prot. morganii should be placed in a separate genus. Since Prot. vulgaris and not Prot. morganii is the type species of the genus Proteus, the rules of nomenclature allow the establishment of a new genus for Prot. morganii. The recognition of the genus Morganella (20) and the species Morganella morganii is appropriate. The neotype strain of $M$. morganii remains ATCC 25830.
At least three hybridization groups exist in Prot. rettgeri. The 1163 group includes strains from the Penner BG 1a, 1b, 2a, 2b, and 3a (34). This group consists of biochemically typical Prot. rettgeri strains. The $666-48$ group contains five strains that are 35 to $50 \%$ related to the typical strains. All of these strains are biochemically atypical. It is quite possible that they do not constitute a single DNA relatedness group. Pending further biochemical and DNA work, they should remain in the species Prot. rettgeri. Both of these Prot. rettgeri groups are more closely related to Providencia species than to Proteus species. We propose that they be placed in the genus Providencia as Providencia rettgeri comb. nov.

The third DNA relatedness group observed in Prot. rettgeri is made up of BG $5 \mathrm{~b}$ strains. By DNA relatedness, these strains are indistinguishable from Prov. stuartii. They must be viewed as urease-positive strains of Prov. stuartii.

All species of Proteus and Providencia are phenylalanine deaminase positive. The urea reaction is relied upon to separate Proteus (Ure ${ }^{+}$) from Providencia. Urease-negative Proteus strains are well documented. In fact, $5 \%$ of Prot. vulgaris, $10 \%$ of Prot mirabilis, and $2 \%$ of $M$. morganii strains are urease negative (13). On the other hand, Prot. rettgeri is listed as $100 \%$ positive (13). However, there are several reports 
TABLE 14. Biochemical reactions at $36 \pm 1^{\circ} \mathrm{C}$ of the seven species in the tribe Proteeae as recognized in this paper

\begin{tabular}{|c|c|c|c|c|c|c|c|}
\hline Test & $\begin{array}{l}\text { Proteus } \\
\text { mirabilis }\end{array}$ & $\begin{array}{l}\text { Proteus } \\
\text { vulgaris }\end{array}$ & $\begin{array}{l}\text { Proteus } \\
\text { myxofa- } \\
\text { ciens }\end{array}$ & $\begin{array}{l}\text { Providen- } \\
\text { cia } \\
\text { alcalifa- } \\
\text { ciens }\end{array}$ & $\begin{array}{c}\text { Providen- } \\
\text { cia } \\
\text { stuartii }\end{array}$ & $\begin{array}{l}\text { Providen- } \\
\quad \text { cia } \\
\text { rettgeri }\end{array}$ & $\begin{array}{c}\text { Morganella } \\
\text { morganii }\end{array}$ \\
\hline Indole production & $-{ }^{a} 2^{b}$ & +98 & - & +99 & +99 & +100 & +99.5 \\
\hline Methyl red test.. & $+9 \overline{9}$ & +93 & + & +99.9 & +100 & +93 & +97 \\
\hline Voges-Proskauer .... & v16 & -0 & + & -0 & -0 & -0 & -0 \\
\hline Citrate (Simmons) utilization & v59 & v11 & + & +98 & +93 & +96 & -0 \\
\hline $\mathrm{H}_{2} \mathrm{~S}(\mathrm{TSI})^{c}$ production $\ldots .$. & +94 & +95 & - & -0 & -0 & -0 & -0 \\
\hline Urease production ......... & v88 & +95 & + & -0 & $\mathrm{v} 15^{d}$ & +99 & +98 \\
\hline Phenylalanine deaminase $\ldots$. & +99 & +100 & + & +97 & +95 & +98 & +95 \\
\hline Lysine decarboxylase $\ldots \ldots \ldots$ & -0 & -0 & - & -0 & -0 & -0 & -0 \\
\hline Arginine dihydrolase $\ldots \ldots \ldots$ & -0 & -0 & - & -0 & -0 & -0 & -0 \\
\hline Ornithine decarboxylase ..... & +99 & -0 & - & -1 & -0 & -0 & +97 \\
\hline Motility, $36^{\circ} \mathrm{C}$. & +95 & +95 & - & +96 & v86 & +94 & v88 \\
\hline Gelatin liquefaction, $22^{\circ} \mathrm{C} \ldots$ & +92 & +91 & + & -0 & -0 & -0 & -0 \\
\hline KCN growth $\ldots \ldots \ldots \ldots$ & +99 & +100 & + & +99 & +99 & +97 & +99 \\
\hline Malonate utilization & -2 & -0 & - & -0 & -0 & -1 & -5 \\
\hline D-Glucose-acid production & +100 & +100 & + & +100 & +100 & +100 & +100 \\
\hline D-Glucose-gas production $\ldots$ & +96 & v86 & + & v85 & -0 & v12 & v86 \\
\hline \multicolumn{8}{|l|}{ Acid from: } \\
\hline$\ldots \ldots \ldots \ldots \ldots$ & -2 & -0 & - & -1 & -4 & -5 & -0 \\
\hline$\ldots \ldots \ldots \ldots \ldots$ & v19 & +95 & + & v13 & v31 & v13 & -1 \\
\hline D-Mannitol $\ldots \ldots \ldots \ldots$ & -0 & -0 & - & -2 & v13 & +99 & -0 \\
\hline Dulcitol $\ldots \ldots \ldots \ldots \ldots$ & -0 & -0 & - & -0 & -0 & -0 & -0 \\
\hline$\ldots \ldots \ldots \ldots$ & -1 & v58 & - & -1 & -2 & v50 & -0 \\
\hline Adonitol $\ldots \ldots \ldots \ldots \ldots$ & -0 & -0 & - & +94 & -4 & +99 & -0 \\
\hline$\ldots \ldots \ldots \ldots \ldots$ & -0 & -0 & - & -1 & +97 & +93 & -0 \\
\hline D-Sorbitol $\ldots \ldots \ldots \ldots$ & -0 & -0 & - & -1 & -3 & -0 & -0 \\
\hline L-Arabinose $\ldots \ldots \ldots \ldots$ & -0 & -0 & - & -1 & -4 & -0 & -0 \\
\hline Raffinose $\ldots \ldots \ldots \ldots$ & -1 & -0 & - & -1 & -5 & -9 & -0 \\
\hline L-Rhamnose $\ldots \ldots \ldots \ldots$ & -2 & -9 & - & -0 & -0 & v75 & -0 \\
\hline Maltose $\ldots \ldots \ldots \ldots \ldots$ & -1 & +96 & + & -1 & -3 & -2 & -0 \\
\hline D-Xylose $\ldots \ldots \ldots \ldots$ & +96 & v89 & - & -1 & -6 & v15 & -0 \\
\hline Trehalose . . . . . . . . & +98 & v30 & + & -4 & +99 & -1 & v14 \\
\hline Cellobiose $\ldots \ldots \ldots \ldots \ldots$ & -2 & -0 & - & -1 & -10 & -4 & -0 \\
\hline$\alpha-\mathrm{CH}_{3}$-glucoside $\ldots \ldots \ldots$ & -0 & v80 & + & -0 & -0 & -2 & -0 \\
\hline Erythritol $\ldots \ldots \ldots \ldots \ldots$ & -0 & -3 & - & -0 & -0 & v78 & -0 \\
\hline Mannose $\ldots \ldots \ldots \ldots \ldots$ & - & - & - & + & + & + & + \\
\hline Esculin $\ldots \ldots \ldots \ldots \ldots$ & -1 & v59 & - & -0 & -0 & v30 & -0 \\
\hline Melibiose $\ldots \ldots \ldots \ldots$ & - & - & - & - & - & - & - \\
\hline D-Arabitol $\ldots \ldots \ldots$ & - & - & - & - & -0 & +99 & - \\
\hline Glycerol . . . . . . . . . & +90 & v70 & + & $\mathrm{v} 12$ & $\mathrm{v} 12$ & v66 & -5 \\
\hline Mucate $\ldots \ldots \ldots \ldots \ldots$ & -0 & -0 & - & -0 & -0 & -0 & -0 \\
\hline Jordan tartrate utilization ... & v88 & +93 & + & +100 & +96 & +96 & +93 \\
\hline Sodium acetate utilization ... & v13 & v23 & - & v30 & v81 & v59 & -0 \\
\hline Lipase production (corn oil) .. & +92 & v87 & + & -0 & -0 & -0 & -0 \\
\hline \multirow{2}{*}{\multicolumn{8}{|c|}{$\begin{array}{l}\text { Deoxyribonuclease production, } \\
25^{\circ} \mathrm{C}\end{array}$}} \\
\hline & $\mathbf{v}$ & $\mathrm{v}$ & - & - & - & - & - \\
\hline $\mathrm{NO}_{3}{ }^{-} \rightarrow \mathrm{NO}_{2}^{-} \ldots \ldots \ldots \ldots$ & +94 & +100 & + & +100 & +100 & +99 & v89 \\
\hline Oxidase production $\ldots \ldots \ldots$ & -0 & -0 & - & -0 & -0 & -0 & -0 \\
\hline $\mathrm{ONPG}^{\boldsymbol{e}}$ production $\ldots \ldots \ldots$ & - & - & - & - & - & - & - \\
\hline Tyrosine clearing $\ldots \ldots \ldots$ & + & + & - & + & + & + & + \\
\hline Pectate liquefaction $\ldots \ldots \ldots$ & - & - & - & - & - & - & - \\
\hline
\end{tabular}
h).

${ }^{a}$ Symbols:,$+ 90 \%$ or greater positive;,$- 10 \%$ or less positive; $v, 10.1$ to $89.9 \%$ positive (all reactions are for 48

${ }^{b}$ The number gives the percentage of strains positive at $48 \mathrm{~h}\left(24 \mathrm{~h}\right.$ for phenylalanine, $\mathrm{NO}_{3}{ }^{-} \rightarrow \mathrm{NO}_{2}{ }^{-}$, and oxidase). The data were tabulated by W. H. Ewing, B. R. Davis, F. W. Hickman, and J. J. Farmer III from over 1,000 cultures admitted to the Center for Disease Control for identification. Some of the data for Prov. rettgeri are taken from the paper by Penner et al. (34). The data for Prot. myxofaciens are based on only one strain, the neotype, ATCC 19692. When limited data are available, no percentage is given.

c TSI, Triple sugar iron.

${ }^{d}$ An estimate based on strains sent to Penner for serotyping.

${ }^{e}$ ONPG, $\alpha$-Nitrophenyl- $\beta$-D-galactopyranoside. 
in the literature describing urease-positive strains of Providencia (Prot. inconstans) $(5,18$, $27,34,35,39-41,43,44)$. The overall biochemical reactions of urease-positive Prov. stuartii strains (or Prot. rettgeri BG 5b) are much closer to Prov. stuartii than to Prot. rettgeri $(34,44)$. The biochemical reactions most helpful in grouping the BG 5b strains with Prov. stuartii and separating them from Prot. rettgeri are trehalose $(+)$, D-mannitol (-), adonitol (-), D-arabitol $(-)$, meso-erythritol (-), L-rhamnose $(-)$, and salicin (-) fermentation. The Prot. rettgeri 5b strains are also serologically related to Providencia. Thus it seems clear that the 3899-72 group (BG 5b) strains are, in fact, urease-positive strains of Prov. stuartii. We thus propose the transfer of Prot. rettgeri BG 5 to Prov. stuartii.

Of 674 Prot. rettgeri strains, Penner described only three BG 4 strains and four BG 5a strains (34). These rare members of 4 and $5 a$ BG have not been tested for DNA relatedness.

The BG of Providencia are shown in Table 12. Adonitol-positive strains of Prov. alcalifaciens BG 1 and 2 are one hybridization group. Together, BG 1 and 2 account for 600 of 633 characterized strains of Prov. alcalifaciens (13). BG 3 strains represent less than $3 \%$ of the total isolates of Prov. alcalifaciens. The eight BG 3 strains studied belong to a hybridization group separate from the other hybridization groups of Prov. alcalifaciens. These strains apparently belong to a new species of Providencia. This recommendation will be made after all available BG 3 strains have been characterized biochemically.

BG 4 of Prov. alcalifaciens also represents less then $3 \%$ of the characterized isolates of Prov. alcalifaciens. They were placed arbitrarily in Prov. alcalifaciens by Ewing et al. (17), who realized that they were not clearly differentiable from Prov. stuartii. The three strains of BG 4 tested were indistinguishable from strains of Prov. stuartii, and we propose that they be transferred to Prov. stuartii. DNAs from all strains of Prov. stuartii BG 5 and 6 were very highly related.

In an evolutionary sense, the protei are at the fringe of the family Enterobacteriaceae. Relatedness between protei (except for $M$. morganii) and other Enterobacteriaceae is between 5 and $15 \%$. This very low level of relatedness to other members of the family, coupled with the large degree of diversity between species of Proteus, can be taken as a basis for arguing that protei be placed in a separate family. Such a decision is unjustified because protei share the morphological and biochemical properties of Enterobacteriaceae and because conserved DNA sequences, such as those that specify ribosomal ribonucleic acid, are highly related between protei and other Enterobacteriaceae (2) and substantially less related between Enterobacteriaceae and members of other families $(25,33)$.

Taxonomy is a science-the science of classification. As such, it is not static, but dynamic, and must respond to changes dictated by new knowledge. A genus should contain a group of related species. All too often, however, genera have been created on the basis of a single common characteristic. The best example is in the family Bacillaceae in which endospore formation is the single criterion for inclusion. The genetic diversity within members of the genera Bacillus and Clostridium within Bacillaceae is as great or greater than that found in the entire family of Enterobacteriaceae.

After reviewing the biochemical, serological, and morphological data on Proteus and Providencia as well as the DNA hybridization data, we proposed three generic changes. In our opinion, these changes are warranted scientifically. As proposed, there are three related species in Proteus, three related species in Providencia, and a single species in Morganella. Additional species will no doubt be added to each of these genera as additional knowledge is accumulated. For example, BG 3 strains of Prov. alcalifaciens, the 666-48 group of Prot. rettgeri, and the 93172 group of Prot. vulgaris are likely candidates for future designation as distinct and separate species.

It should be emphasized that these proposals are not new concepts. Biochemical $(7,14,20,26$, $36-38)$, serological $(7,26,34)$, and morphological differences among species of Proteus and Providencia have been known to exist for 30 years. Investigators recognized that the tribe Proteeae should eventually contain more than one genus. Some made specific recommendations $(20,26$, $36-38$ ), whereas others preferred to maintain the single genus Proteus until additional data were available. Those data are now available and are consistent with the three genera we recognize herein.

A paper concerning the type or neotype strains of the species discussed herein is in preparation.

\section{REPRINT REQUESTS}

Address reprint requests to: Dr. Don J. Brenner, Enteric Section, Building 1, Room B311, Center for Disease Control, Atlanta, GA 30033.

\section{LTERATURE CITED}

1. Brenner, D. J., R. V. Citarella, and S. Falkow. 1968 Genetic and molecular relationships among the Enterobacteriaceae. Spisy Prirodoved. Fak. Univ. J. E. Purkyne Brne K43:255-278.

2. Brenner, D. J., G. R. Fanning, K. E. Johnson, R. V. Citarella, and S. Falkow. 1969. Polynucleotide se- 
quence relationships among members of Enterobacte riaceae. J. Bacteriol. 98:637-650.

3. Britten, R. J. 1968. An instructive glossary. Carnegie Inst. Washington Yearb. 66:68-73.

4. Britten, R. J., and D. E. Kohne. 1966. Nucleotide sequence repetition in DNA. Carnegie Inst. Washington Yearb. 65:78-106.

5. Carpenter, P. 1964. The Proteus-Providence group. Recent Adv. Clin. Pathol. Series 4:12-23.

6. Clausen, T. 1968. Measurement of ${ }^{1 / 2} \mathrm{P}$ activity in a liquid scintillation counter without the use of a scintillator. Anal. Biochem. 22:70-73.

7. Coetzee, J. N. 1972. Genetics of the Proteus group. Annu. Rev. Microbiol. 26:23-54.

8. Coetzee, J. N. 1972. R. factors from Proteus rettgeri. J. Gen. Microbiol. 72:543-552.

9. Coetzee, J. N., N. Datta, R. W. Hedges, and P. C. Appelbaum. 1973. Transduction of $\mathrm{R}$ factors in Proteus mirabilis and $P$. rettgeri. J. Gen. Microbiol. 76:355-368.

10. Cosenza, B. J., and J. D. Podgwaite. 1966. A new species of Proteus isolated from larvae of the gypsy moth Porthetria dispar (L.). J. Microbiol. Serol. 32:187-191.

11. De Ley, J. 1968. In T. Dobzhansky, M. K. Hecht, and W. C. Steere (ed.), Evolutionary biology. Appleton-Century-Crofts, New York.

12. Edwards, L. D., A. Cross, S. Levin, and W. Landau. 1974. Outbreak of a nosocomial infection with a strain of Proteus rettgeri resistant to many antimicrobials. Am. J. Clin. Pathol. 61:41-46.

13. Edwards, P. R., and W. H. Ewing. 1972. Identification of Enterobacteriaceae, 3rd ed. Burgess Publishing Co., Minneapolis.

14. Ewing, W. H. 1958. The nomenclature of the Proteus and Providence groups. Int. Bull. Bacteriol. Nomencl. Taxon. 8:17-22.

15. Ewing, W. H. 1962. The tribe Proteae: its nomenclature and taxonomy. Int. Bull. Bacteriol. Nomencl. Taxon. 12:93-102.

16. Ewing, W. H., and B. R. Davis. 1972. Biochemical characterization of the species of Proteus. Public Health Lab. 30:46-57.

17. Ewing, W. H., B. R. Davis, and J. V. Sikes. 1972. Biochemical characterization of Providencia. Public Health Lab. 30:25-38.

18. Ewing, W. H., K. E. Tanner, and D. A. Dennard. 1954. The Providence group: an intermediate group of enteric bacteria. J. Infect. Dis. 94:134-140.

19. Falkow, S., I. R. Ryman, and O. Washington. 1962 Deoxyribonucleic acid base composition of Proteus and Providence organisms. J. Bacteriol. 83:1318-1321.

20. Fulton, M. 1943. The identity of Bacterium columbensis Castellani. J. Bacteriol. 46:79-82.

21. Hedges, R. W. 1974. R factors from Providence. J. Gen. Microbiol. 81:171-181.

22. Hedges, R. W., and H. Datta. 1973. R factors from Proteus morganii. J. Gen. Microbiol. 77:249-259.

23. Hill, L. R. 1966. An index to deoxyribonucleic acid base compositions of bacterial species. J. Gen. Microbiol. 44:419-437.

24. Johnson, R., R. R. Colwell, R. Sakazaki, and K. Tamura. 1975. Numerical taxonomy study of the-
Enterobacteriaceae. Int. J. Syst. Bacteriol. 25:12-37.

25. Kato, Y., and E. T. Bolton. 1964. Relationships among some enterobacteria. Carnegie Inst. Washington Yearb. 63:372-373.

26. Kauffmann, F. 1954. Enterobacteriaceae, 2nd ed. Munksgaard, Copenhagen.

27. Kholodkova, E. V. 1972. Characteristics of enzymatic properties of a collection of bacteria of Providencia genus. Zh. Mikrobiol. Immunobiol. 49:50-53.

28. Laird, C. D., B. L. McConaughy, and B. J. McCarthy. 1969. On the rate of fixation of nucleotide substitutions in evolution. Nature (London) 224:149-154.

29. Lautrop, H. 1974. Genus X. Proteus Hauser 1885, 12, p. 327-330. In R. E. Buchanan and N. E. Gibbons (ed.), Bergey's manual of determinative bacteriology, 8th ed. The Williams and Wilkins Co., Baltimore

30. Matsen, J. M., D. J. Blazevic, J. A. Ryan, and W. H. Ewing. 1972. Characterization of indole-positive Proteus mirabilis. Appl. Microbiol. 23:592-594.

31. Namioka, S., and R. Sakazaki. 1958. Etude sur les Rettgerella. Ann. Inst. Pasteur Paris 94:485-499.

32. Overturf, G. D., J. Wilkens, and R. Ressler. 1974. Emergence of resistance of Providencia stuartii to multiple antibiotics: speciation and biochemical characterization of Providencia. J. Infect. Dis. 129:353-357.

33. Pace, B., and L. L. Campbell. 1971. Homology of ribosomal ribonucleic acid of diverse bacterial species with Escherichia coli and Bacillus stearothermophilus. J. Bacteriol. 107:543-547.

34. Penner, J. L., N. A. Hinton, and J. Hennessy. 1975. Biochemical differentiation of Proteus rettgeri. J. Clin. Microbiol. 1:136-142.

35. Penner, J. L., N. A. Hinton, G. R. Whiteley, and J. N. Hennessy. 1976. Variation in urease activity of endemic hospital strains of Proteus rettgeri and Providencia stuartii. J. Infect. Dis. 134:370-376.

36. Proom, H. 1955. Amine production and nutrition in the Providence group. J. Gen. Microbiol. 13:170-175.

37. Proom, H., and A.J. Woiwood. 1951. Amine production in the genus Proteus. J. Gen. Microbiol. 5:930-938.

38. Rauss, K. 1962. A proposal for the nomenclature and classification of the Proteus and Providencia groups. Int. Bull. Bacteriol. Nomencl. Taxon. 12:53-63.

39. Sen, R. 1962. Some observations on the biochemical characters of the Providence group of the family Enterobacteriaceae isolated in Ibadan, Nigeria. Indian J. Med Res. 50:627-629.

40. Shaw, C., and P. H. Clarke. 1965. Biochemical classification of Proteus and Providence cultures. J. Gen. Microbiol. 13:155-161.

41. Singer, J., and J. Bar-Chay, 1954. Biochemical investigation of Providence strains and their relationship to the Proteus group. J. Hyg. 52:1-8.

42. Steigerwalt, A. G., G. R. Fanning, M. A. Fife-Asbury, and D. J. Brenner. 1976. DNA relatedness among species of Enterobacter and Serratia. Can. J. Microbiol. 22:121-127.

43. Stuart, C. A., K. M. Wheeler, and V. McGann. 1946. Further studies on one anaerogenic paracolon organism, type 29911. J. Bacteriol. 52:431-438.

44. Ursing, J. 1974. Biochemical study of Proteus inconstans (Providencia). Occurrence of urease positive strains. Acta. Pathol. Microbiol. Scand. Sect. B 82:527-532. 